\title{
The heART of Activism: Stories of Community Engagement
}

\author{
David Monk, Bruno de Oliviera Jayme, Emilie Salvi
}

\begin{abstract}
This paper invites the reader to consider the power and potential of art for public engagement, and its use in social movement learning and in demanding the world we want now. The authors frame social movements as important sites of scholarship and learning. They emphasize that by applying creative strategies to engage in critical thought about the nature of the world and one's position in it, artforms have the potential to make essential contributions to social change. Inspired by literature related to critical art-based learning and learning in social movements, the authors explore representations of protest art and public art exhibitions. They contextualize their writing with stories of mobile art exhibits in Sao Paulo, the 'maple spring' in Montreal (Tiotia:ke in the language of the Kanien'kehá:ka), and anti-Bill C-51 protests in Lekwungen territory (Victoria, British Columbia). They present and reflect on their own experiences of using art as engagement and as a representation of voice in public demonstrations.
\end{abstract}

KEYWorDs Critical pedagogy, art-based learning, learning in social movements, adult education

\begin{abstract}
Art, an embodiment of public pedagogy, is imperative to our work as critically engaged young scholars, community activists, and radically loving human beings. Often existing outside the milieu of capitalist consumption, art as resistance constitutes one of the few political and pedagogical spaces that remains free-where artists everywhere use their soulful imaginations to resist oppressions, to dream of justice, and to speak truth to power (Darder, 2011, p. 799).
\end{abstract}

The above quote by Antonia Darder, a popular academic, poet, artist, and community organizer in many ways summarizes the goals of our explorations in highlighting the relevance of community art as transformative tools in social movements. Transformation, in the context of community art (as resistance) refers to a social phenomenon in which individuals, through collective practices, and critical reflection, experience a profound understanding of themselves and their words, in ways in which they act and react upon constraints that may affect their wellbeing. Such phenomenon is what Freire (1970) identifies as conscientização. As a result of this process, individuals shift their perspectives of, and engagement in, the world. Through this lens, we intertwine theories of social movement learning and arts-based learning as critical pedagogies to describe and articulate the potential of community arts as powerful tools in/for 
social justice, community engagement and conscientizção, with the ultimate goal of promoting social change. To illustrate this claim, we present three different and yet interrelated real stories of community art as activism experienced by the authors. These stories, unfolding in two different Canadian cities (Lekwungen-Victoria, British Columbia, and Tiotia:ke-Montreal, Quebec) as well as in the city of Sao Paulo, Brazil, are examples of how dialogue appears as a pedagogical tool, and as methods of (de)constructing political discourses.

We interpret transformative learning from a Freirean and holistic perspective as presented by Edward O'Sullivan (1999). In theory, after experiencing discomfort or disorientation, often escalated to anger, individuals reflect on their position in their world(s), shift their perspective, and act consciously for social justice. The critical and social justice components are important for our conceptualization of art as opening spaces of disruption in activism. Drawing upon transformative learning theory, this article explores how these frameworks help us to understand the need to broaden our perspectives on a pedagogy promoting creativity and opening spaces for community art as dialogical spaces.

\section{Art as Disruption}

Once upon a time there was quite a shy little girl, who did not really participate much in class. One day, the teacher finds her in the corner of the classroom drawing intensely. The teacher approaches her and says:

"Oh! That is nice. What is it?"

The little girl, without looking up at the teacher answered:

"I'm drawing a picture of God."

The teacher, now intrigued, said to the girl:

"That's impossible. No one knows what God looks like."

The little girl, looked up to the teacher and said:

"They will in a minute."

This story is borrowed from Sir Ken Robinson (2006) referring to encouraging teaching for creativity. For the authors, this excerpt also illustrates that art can open dialogical spaces for critically interrogating the world. In this case, the young girl, through her art opened a space that challenged the teacher's schemata and asked them to reconceptualize the impossible. Mahmoudi, Khoshnood, and Babaei (2014) suggest that such spaces enable individuals to increase conscientização, and mediate transformative learning. Freire (1970) accentuated that dialogue develops self reflection within culture and history, leading to (re)imagination of different realities for ourselves and the world surrounding us. The arts have the power to open up cracks in social norms and hidden injustice by provoking soulful reflection, dialogue, and reimagination of the world. This is synchronous with the goals of social movements, which Hall (2009) describes as seeking to disrupt the status quo and demand the world we want now. We therefore argue that the arts as critical pedagogy are valuable tools for transformative learning and have the potential to catalyze transformative learning and social change through activism and social movements. It is from this radical tradition of critical pedagogy, transformative learning and social change that we interpret community art as activism.

Engaged Scholar Journal: Community-Engaged Research, Teaching, and Learning 
In many parts of the Western world, the arts have been historically defined by European standards and traditions - that is, predominantly produced and judged by elitist, white, and masculine measures, aimed at or supported by the wealthiest and the most powerful institutions (Janis \& Mann, 1977). According to Dewey (1934), such powerful institutions play an important role in reinforcing the production (and large reproduction) of artwork (Benjamim, 1999), much like any other product for sale in the market. In the second half of the $20^{\text {th }}$ century, numerous artistic interventions challenged the ways in which people perceived not only their realities, but the standardization of art. For example, Dadaist cultural movements that emerged in Zurich, Switzerland during the Second World War mobilized millions of people worldwide to protest against the barbarism of the war. Dadá, besides being an anti-war movement, was also an anti-bourgeois and anti-(institutional) art movement that encompassed poetry, visual arts, and theatre (Gale, Ades, Aguer \& Fanes, 2007). It not only challenged the elitism and standardization of art, but it also invited the general public to explore different ways of perceiving art by contextualizing it within what was previously seen as mundane or vulgar historical and cultural contexts (Dewey, 1934). This sort of intervention into the privileged institutionalized forms of art challenged the very function of art, within positivist elitist European traditions, as being "emotive rather than informative" (Eisner, 2008, p. 3) or transformative.

Community art as disruption challenges this very notion of arts as being only emotive. Ideally community art uses and represents often ignored voices to surface problems and inequalities, and reflect individual and community needs, desires, and hopes for a better future. From this perspective, community art portrays an alternative reality for participants and the general public. More so, community art mediates compassion and empathy amongst those involved in the artmaking process. This is not to say that community art does not, or should not evoke emotions, but their potential to communicate sensitive issues should not be neglected, as well as their ability to bring forth different political views, increase cultural sensitivity, and develop alternative aesthetics.

\section{Community Art as Activism}

Community art is an experiential, inclusive, and participatory type of art, where artists work collaboratively with citizens in grassroots contexts to create artworks that are of public interests. This type of participatory artmaking process emerged in the political and activist scenario of the 1960s, which at the time aimed to popularize the arts, and return it to the citizens. Community art has a history of challenging dominant cultural and political views in an effort to respond to hegemonic status quo, "evolving around the notion of empowerment through participation in the creative process" (Krenksy \& Steffen, 2009, p. 12). Krensky and Steffen (2009) emphasize that in community art everyone is an artist and "the production of art by people who don't define themselves as artists is a radical and transformative act" (p. 12). From this perspective, community art results in social change because it challenges social norms, hierarchy, patriarchal societies, and elitist European arts through its collaborative artmaking process. In the context of community art, the stories presented here describe and articulate how activists, artists and the general public co-create art to disrupt social norms and 
respond to social injustice. This practice invites educators, activists, and the public to engage in soulful dialogue and dream of justice and a better society. This practice is at the very heART of our stories of activism.

\section{Community Art in Social Movements}

A vast amount of literature within art education claims the arts open up spaces for personal and social transformations (e.g., Belfiore \& Bennet, 2008; Eisner, 2004; Greene, 2000; Holden, 2008). Within the context of social movements, the arts can be a powerful tool for transformation by opening up spaces for soulful imagination and dialogue. They force dialogue and thinking about often hidden or ignored oppressions, while giving voice to the values and ideology of activists.

They address important societal questions, and construct and build on ideologies of social progress (Milbrandt, 2010). Typically, visual images inspire a sense of belonging and identity to the activist's cause. By using codes and conventions representing not just a verbal text but an emotional tone, art increases community engagement (Milbrandt, 2010). The arts unite activists and community often having an impact across boundaries of age, socio-economic status, country, and ideology.

Art in social movements can establish an emotional tone to bring a sense of unity at the beginning of an action and sense of closure to wounds. For example, as Milbrandt (2010) explains, a powerful and emotional visual artistic reminder of Acquired Immunodeficiency Syndrome is the AIDS Memorial Quilt. With more than 44,000 three-by six-foot panels have been sewn together into a commemorative community artwork, every panel is designed to honour the memory of a loved one who lost their life to AIDS.

In many ways community activist art has been a way to develop a voice representing the real needs of a community, thinking critically to build a solid foundation for democratic citizenship. Even during cases of extreme oppression, art has proven to be an empowering tool, for instance in the form of folktales, theatre, jokes, folk art and songs (Scott, 1992). These art mediums have a strong cultural impact and typically become a powerful element within any movement.

\section{Social Movements as Sites of Intervention}

Rather than the traditional and individual model of academic knowledge production, contemporary dialogues on social movements as agents of change focus on counter hegemonic practices through alternative forms of engagement, including community art. According to Freire (1970), it is through critical conversation that we are able to reflect upon our own realities. Freire suggests that reflection allows us to position ourselves within our culture and history, to (re)imagine different realities and the world surrounding us, with the ultimate goal of social change. Tandon, Hall, and Tremblay (2015) suggest that a reconception of legitimate ways of knowing and being is essential to social change. Extending these concepts to the social movements arena, Mota and Esteves (2014) assert that social movements have potential to embody change and limit reproducing the status quo through legitimizing subaltern 
epistemologies: "At the heart of this is the pedagogical, understood as those processes, practices and philosophies that enable the unlearning of hegemonic forms of life, social relationships and subjectivities" (p. 21). Central to the goal of social movements is challenging hegemonic power by taking back spaces of domination, often maintained through the silence of the status quo and police control. Marcuse (1965) explained this process by which the liberal state together with corporations assert democratic tolerance, as they insist that radical activists are subversive of the very ideals on which our society is based. This is a process whereby anyone who speaks out is portrayed as violent, a troublemaker disrupting the public peace with the goal of destroying society. Somma (2006) described this through the post 9/11 crackdown on activists, emphasizing the patriarchal language used by corporations and government such as protecting freedom and democracy. It is therefore essential for social movements to both take back spaces of domination and engage in critical pedagogy about freedom, democracy, and the status quo. This is synonymous with the goals of critical art-based learning as indicated by Clover and Stalker (2007) who document how many states using neoliberal policies of austerity have been moving away from social traditions. Clover and Stalker use community art projects to empower women, who have been most impacted by these cuts, to engage actively in social justice. Community art provides an excellent opportunity for engagement and is therefore an important critical pedagogical tool for social movements.

Critical adult educators and community organizations are increasingly relying on artsbased educational approaches as a way to react to social issues and challenge cultural norms (see Clover 2012; Clover \& Stalker, 2007). Darder (2011) outlines the value of using art in the context of protests as a tool for fighting against power and opening new spaces for hope and social justice. She suggests that the more engaging the process, the more likely people will feel a personal connection to the issue increasing the likelihood of change. Using alternative methods and strategies in knowledge creation engages people with the world in a different way, in itself challenging normative conceptions of knowledge, while (in the context of social action) opening up spaces for engaging in social justice. Collins (2006) emphasizes the significance of art in this context as critical pedagogy. Elmbourg (2010) explains that when conceiving art as critical pedagogy it is essential to empower "people to own their questions, their minds, and their bodies" (p. 71). Further to this and in relation to social movements, research published by Clover and Craig (2009) demonstrates that art develops trust and community among the artists working together, as well as pride and consequent confidence to think creatively about solutions to social problems. It can also empower them to speak out and take action.

Ultimately, community art encourages learners in producing sites of knowledge where critical learning, social consciousness, and participation inspire democratic societies. It is with this perspective that we turn to our stories where art is central to activism and social change. The first story centres on art creation for social change accentuating the value of art in shifting knowledge hierarchies and challenging public spaces and cultural representations. The second and third stories examine art as a tool for engagement and learning in social movements, giving examples of direct grassroots action. The second and third stories thus complement and build on the foundations of the first story. 


\section{First story: Recycling stories}

It's ten in the morning, June $22^{\text {nd }}, 2012$ in a metropolis where every hour is rush hour. There are people everywhere hastening to get places and shoving into public transportation. The helicopter air traffic is chaotic, and cars and motorcycles honk their way onto the pavement. Street vendors try to sell anything they can to make a living. An audience contemplates a preacher who loudly announces "Jesus is coming". Police and ambulance sirens are heard from miles away. Although it is not summer, the heat is unbearable, the air pollution is heavy, and the city lacks green space. The warmth accentuates the stench of garbage not yet collected by city workers. A group of executive men sweating inside their suit jackets ignores a panhandler begging for food.

This could be just an ordinary day in the city of São Paulo, Brazil, except that at this moment, a van drives through the crowd onto the main public square and parks in front of City Hall. Five people get out and start unloading art supplies. A set of 12 easels is unfolded and artworks are carefully hung on them. On the other side, an old bus is parking. Its door opens and a young crowd jumps out and blasts hip-hop music. Each one grabs a can of spray paint and starts to graffiti the bus. In between two light poles, a big banner has been hung that reads in bold letters: "Recycling Stories-A mobile art gallery." At that moment the chaos in that public square seems to stop, transformed now into an open-air art gallery.

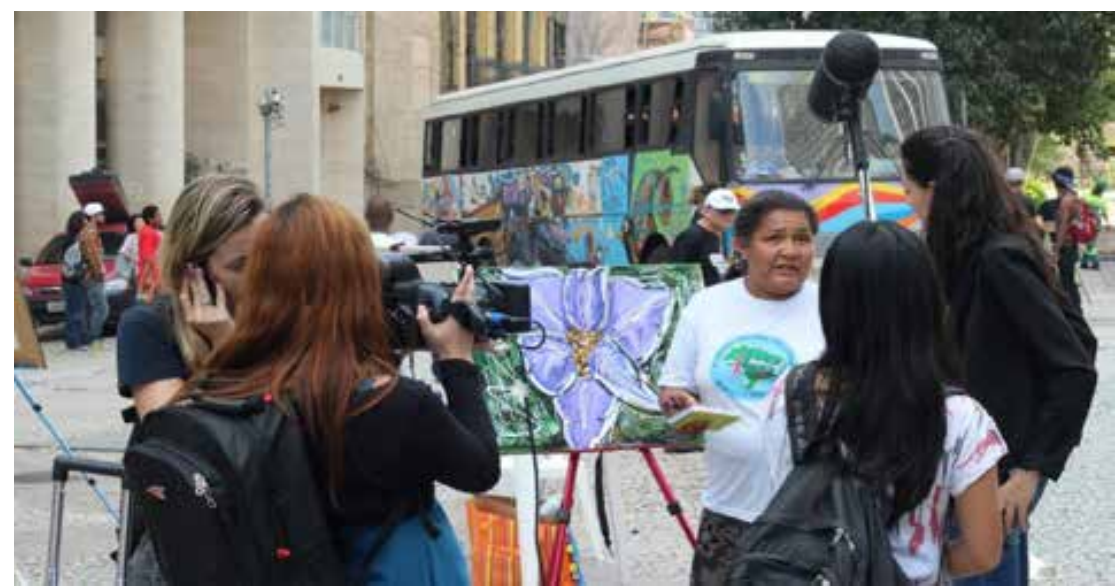

Figure 1. Setting up the mobile art gallery. Photo credit: Bruno de Oliveira Jayme

The above story is one example of many mobile art galleries created by Members of the National Recycling Social Movement in Brazil. Traditionally these workers are looked down on socially. During the art shows, visitors were able to freely walk around the artwork and have interactions with recyclers. Most of the conversation regarded the politics around recyclers' work. From these dialogues, new recycling networks for cooperation were established and many stories emerged. These mobile art galleries aimed to create dialogue amongst recyclers and the general public about the work performed by recyclers, to make visible to the public the 
importance of their work, and, ultimately, to decrease the prejudice they suffer.

Community created art galleries break taboos when people's personal experiences are shared, bringing forth social identities of a community. The Recycling Stories project was created by the community for the community, and it challenged the confined walls of traditional art institutions which often are disconnected from the real world of local communities. The Recycling Stories deterritorialized traditional art standpoints by challenging views of who can produce art and where art can be displayed. More specifically, it first made art more democratic by tackling into a territory once occupied by formal trained artists. Such democracy of the arts welcomed ordinary people from different backgrounds to share with the general public contemporary and relevant stories about themselves including their daily struggles working on the streets and living on the edge of extreme poverty.

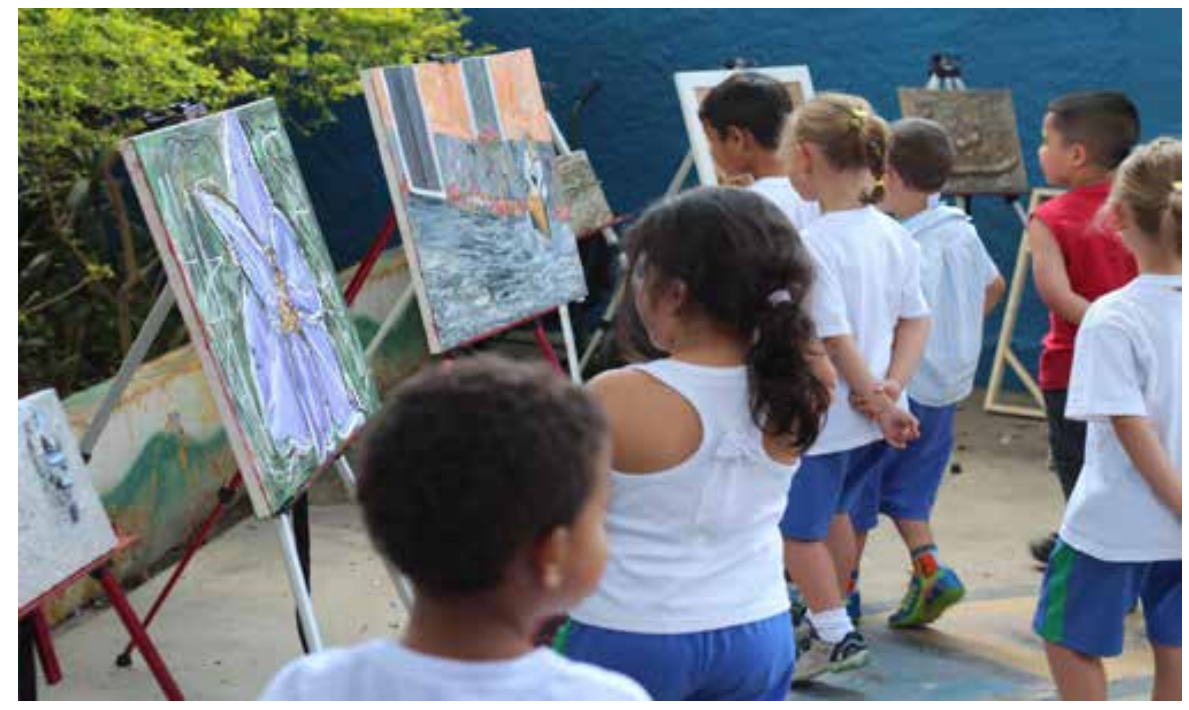

Figure 2. Mobile art gallery display.

Photo Credit: Bruno De Olivera Jayme

Through these mobile art galleries various actors (e.g., recyclers and the public) divesting voices, defining the outcomes and future inquiries. The Recycling Stories allowed the community to choose which stories they were willing to share. This helped recyclers to create their own identity and to make their reality visible, inviting the public into a critical reflection about social justice. This aspect of our art gallery is important because when members of the community create their own artworks and curate their exhibit, we do not take the risk of hiding or misrepresenting stories, and perpetuating the privileged status quo. In other words, the Recycling Stories, de-hierarchized knowledge production and mobilization. Additionally, the Recycling Stories created alternative and affective spaces within everyday life. This was evident when our gallery disrupted a public space in front of São Paulo City Hall gaining the attention of politicians, media, and the public. At that moment, at that public square, conventional use 
of public space was challenged, power questioned, alternative social dynamics established, and a hopeful atmosphere created.

\section{Second story: Bill C-51}

The second story examines a major rally that took place in unceded Lekwungen territory (Victoria, British Columbia, Canada) in protest of a proposed draconian law, Bill C-51, limiting free speech and labelling social activists as terrorists. Two of the authors helped to organize the rally by introducing and facilitating a co-created community art project. This account is based on the analysis of personal reflections and notes taken by the author-participant-organizers during the rally_along with photos of the event. Ellis, Adams, and Bochner (2011) define this method of qualitative research as Systematic Sociological Introspection (SSI), which is commonly used in autoethnography. The goal of autoethnography is to share an experience and reflections on the experience hoping to create personal ties with readers who identify with the experience and reflect on it carefully in the context of their own lives. We share our story about the process of engagement and personal interpretation of the impact of art in this C-51 protest with the hope to inspire.

Bill C-51 was introduced as an anti-terrorism act in January 2015 by the Conservative Party of Canada. It was immediately subject to major and ubiquitous public outcry against the increased power given to police forces to impinge on public privacy and human rights (see Canadian Journalists for Free Expression, 2015; Canadian Bar Association, 2015), especially sovereign First Nations (For First Nations' reactions see: Assembly of First Nations, 2015). It was generally seen as a means for forcing through a pipeline against the will of many First Nations and environmentalists.

The morning of the protest, around 1000 protesters gathered in a public space and marched together down several main streets, stopping at a major intersection in the downtown core to leave messages on the road in chalk, and culminating in an accessible public space with a stage and microphones, where there were speakers, musicians, and art. Jordan (1995) has outlined the importance of solidarity in a large movement as one that builds on a collective we among a wide variety of interested groups, and that was one of the first things we noticed as people began piling into the square with their signs. First Nations, Religious groups, anarchists, communists, political representatives, and activists from almost all parties, union leaders, student groups, environmentalists, and many more took the streets to show their opposition to the bill. One of the key goals was to reclaim public space; this was done by occupying the streets. As Jordan (1995) points out, it is important for the organizers to avoid authoritarian control/ cooptation by keeping the police unaware of the route, so that they found themselves catching up to block streets rather than allowing the protest to happen. After all, the protest was opposing an expanded authoritarian police state. In taking to the streets in non violent direct action, protesters asserted their right to speak out to power and sent a strong message to the media and to government, demanding, as Hall (2009) puts it, "the world we want now" (p. 9). We feel that art was an integral part of the C-51 protests and there are three ways in which it was used: the use of signs and masks, chalking the streets, and a collective piece of artwork.

Engaged Scholar Journal: Community-Engaged Research, Teaching, and Learning 
All of which were used to communicate people's dissent for Bill C-51 and the authoritarian state. It was more than just communication, however. The significance of using art to disrupt was particularly important in this instance because of the authoritarian measures we were contesting. Authoritarianism emphasizes conformity and normalcy and we were intentional about using art to encourage creativity and freedom of thought. Song and dance were also large components, although not discussed here, these also contributed to a rambunctious and festive atmosphere of freedom and dissent.

The use of signs is quite common in protests and rallies. They are typically used to convey a message to a wider audience-passersby, bystanders, and media. This protest was no different. Organizers created a massive banner that lead the demonstration saying "stop Bill C-51", and distributed yellow cloth pins with "stop C51" written on them along with full face masks of the political leaders who supported the Bill: Justin Trudeau and Stephen Harper. A popular sign reflected the movie "Kill Bill" using the same colours as the popular video and adding " $\mathrm{C}$ 51 " at the end. There were a number of signs that linked bill C-51 to Nazism, fascism, and a destruction of democracy. Another common theme was a demand for the protection of rights and freedoms, and a removal of Harper from office.

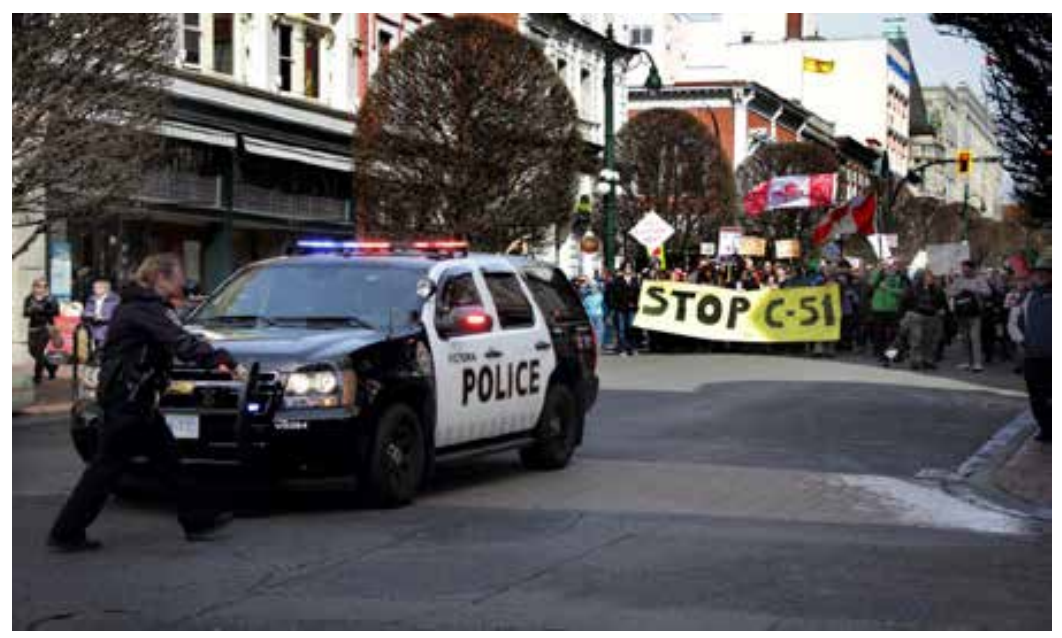

Figure 3. Protestors marching.

Photo Credit: Bruce Dean (Professional Recreationist)

About halfway through the protest march, in a major intersection in a shopping and eating hub downtown, the organizers halted the march asked people to sit. They then distributed chalk to protesters, asking them to write a message to their politicians about what they thought of Bill C-51. The idea was to have a bit of a party for a while in the intersection and leave a lasting message for people passing by.

These were all important ways of giving voice to voices that are otherwise alienated and/or not represented, and of course disrupting the city to provoke thought about the consequences of the bill. At first many of the protesters were visibly hesitant and unsure. There were a 
number of people waiting for buses and cars stopped all around, and because it was not your traditional group of hardened protesters, there was a distinct feeling of nervousness among some of the protesters as we handed out chalk and prepared to stay put for a while. As chalk distributors, we remember thinking at this point that we were going to lose people. A few people even declined taking it at first, until they saw other people starting to drop to the ground and write their messages. Eventually almost everybody obtained some chalk, and momentum was restored as people shared their messages using art, poetry, and slogans. Drums came out, a circle was formed, people discussed their work, and we sang some songs before moving on. Common themes included stopping Bill C-51, opposing Harper and fascism, and (re)claiming democracy and freedom.

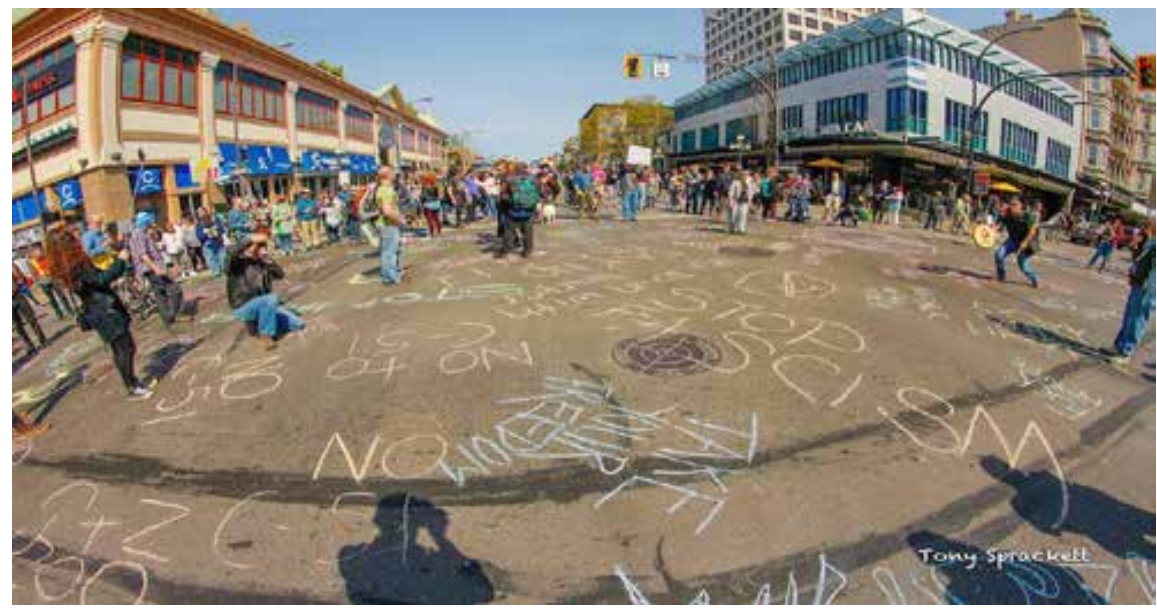

Figure 4. Chalking up the intersection. Photo Credit: Tony Sprackett

Using this collective artmaking process played a significant role in empowering those protesters who were uncertain about being in the streets to begin with. This was evident through the shifting atmosphere and visible demeanour observed. Stopping traffic and disrupting the normal flow of life in the city was uncomfortable for some people and physically stopping forced them to think more about the power and potential of their voice and actions in collaboration with others. As organizers we hope that the point of blocking the main street and leaving our artwork helped participants to realize the importance of disrupting the status quo. It is difficult to gauge the extent this was successful; however, we did attempt to engage in individual conversations about our artwork as disruption. There was also an experiential element of disruption. Firstly, as we were stopped, curious bystanders gathered to have a look at the art, with some even adding to it. Secondly there was an element of self disruption, as people had to wrestle with and overcome their vulnerability and nervousness of disrupting other people's lives in a very visible way. This action also had an empowering impact as people overcame their fear and vulnerability they appeared to become more confident. The art played a big role in moving through this process. Additionally, the participative nature of 
actively marking up a public intersection in a lasting way created a deeper and more personal connection to the issues. Collectively marking up the intersection not only empowered people to share their feelings in a message that would last beyond the protest, it also brought the group together. This was evident in the observed energy shift; protestors were hesitant at first to even take the chalk, but slowly gained confidence to write and draw their messages and eventually even formed a circle and sang and danced. Certainly after blocking the street for 20 minutes, it was a visibly and audibly more unified, and assertive crowd that proceeded along their route.

A second outcome was the opportunity for everyone to express their feelings about the bill, the government, and democracy in an impromptu exhibition on the streets of the city. Milbrandt (2010) identified the impact of art in protest as publicizing actors perspective, values, and ideology. This use of public space left a direct message to thousands of people who pass through the city every day. It was an unavoidable art exhibit engaging people on an important public issue, and an element of the protest that remained even after the protesters passed, thus making the disruption and engagement last longer and impact more people. As organizers we feel that this tactic worked very well. We personally have had many discussions about democracy, the right to protest and Bill C-51 when back in the area after the protest. For example, a few days after the protest one of the authors engaged with a tourist from Germany who was trying to understand what all the writing was about. The author was able to point out and explain about some remnant of his own message. The author certainly felt empowered and engaged and proud at his participation in that moment. The tourist was surprised that this was happening in Canada. We share this example to show the potential for dialogue opened by art, but also to demonstrate how difficult it is to capture the extent and depth of the impact art can have on both individuals and the world. In my case, I continued to participate actively in other events, perhaps partially as a result of the feeling of empowerment. In the case of the German, it is impossible to know if he went on and shared the dialogue with other travellers and in his own country.

The promenade through the city culminated in a popular public square with a series of speakers and musical performances. This is where a good deal of informal learning took place. Our main contribution as organizers was facilitating a collective piece of artwork consisted of a large canvas four meters by one meter, with a background of multiple smaller images of the Canadian parliament buildings faded into it. The art project took place in a public square at the end of the march. Accompanied by music and speeches, protesters and curious passersby were invited

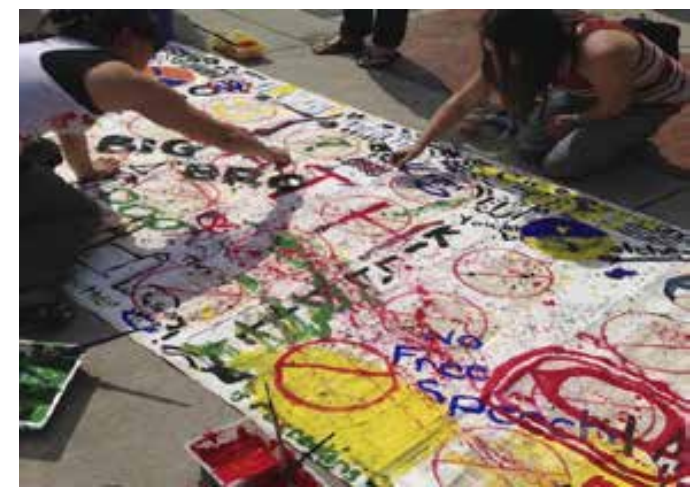

Figure 5. Capturing layers of voices about C-51. Photo Credit: Bruno de Oliveira Jayme 
to lend their voices however they desired on the canvas.

The result of the tapestry was a multi-layered, multi-lingual mix of words and pictures reflecting democratic views, freedom of speech, and a broader theme of solidarity among causes and oppressions. The tapestry (Figure 5) was painted on the back drop of several copies of the Canadian Charter of Rights and Freedoms which were ironed into the tapestry. Several important elements emerged from this artmaking process. Primarily, it provided a creative venue for people to communicate their perspectives about the bill, the government, and democracy in an impromptu exhibition on the streets of the city. Chwe (1998) suggests that creative methods of stimulation and engagement (such as this one) are more likely to leave a deeper social and personal impact. The process of creating art engaged and drew in a crowd of passersby who did not feel intimidated by the art and were willing to learn about and discuss the bill. It was an unavoidable art exhibit facilitated by a professional artist. Most of the dialogue was informal as people contributed together to the art. There was also an element of reflection as the facilitator and co-artists asked questions of spectators and contributors about the art. There was a constant grouping of people around the art all afternoon. The active element of contributing to a collective art creation opened a space for a deeper discussion on a range of issues in our society, not only Bill C51. Cole and McIntyre (2003) suggest the arts are powerful tools of knowledge mobilization because of their ability to evoke emotions and deeper political complexities. Thompson (2002) points out that in creating art, people enter into a space of uncertainty, and it is in these spaces that deeper engagement can take place. While signs, speakers, music, and physically occupying public spaces were important for engaging people, this collaborative artmaking experience evoked deeper conversations as the artists painted a picture of the world they want to live in now.

In the process of engaging in the art, conversations naturally emerged among the participants, many of whom developed a more profound understanding of the impacts of Bill C-51. Questions about democracy, its meaning, who is heard and who is not were raised and discussed throughout the process. The art also provided an element of deeper connections, through collaboration and conversation of people who did not know each other. There were people from very different walks of life who engaged with one another and learned a little more from each other. People jumped in and out of the canvas discussing the work and its meaning together. It formed a significant part of the learning and engagement of the protest, and the tapestry itself was later (and still is) used as a basis for engagement in other art activist educational forums in the city.

\section{Third story: Québec Maple Spring}

Throughout history, Canadian student activists are known to have spearheaded social change. The 2012 Québec Maple Spring [Printemps érable], also referred to as "Québec Spring" [Printemps quebecois] and the Québec student movement, is celebrated as the largest student protest movement in Canadian history. The following story is a reflection of the author's analysis, based on academic literature, relevant websites, news reports, and an interview with a key organizer describing the impact of learning and engagement through art. 
The movement began in 2011, when more than 20,000 students, in the province of Québec, including hundreds of thousands of student activists from CEGEPs (an acronym for Collège d'enseignement général et professionnel [General and Professional College]), and universities, began protesting against Jean Charest's Parti Liberal de Quebec (PLQ) government's proposed five-year 75 percent increase to raise tuition (Spiegel, 2012). Despite massive protests and demonstrations, the negotiations with the Jean Charest government were unsuccessful. As reported by Montréal student activists, Sam Bick and Mehreen Rushdia (2012), on May 22, 2012 an estimated 300,000 to 400,000 protesters marched against the government's refusal to acknowledge the students' demands. The strikes began as protests against tuition fees increase and grew into a popular movement, building solidarity against the austerity agenda. In mid-May, the Québec government passed Bill 78, a government law aimed to ban all nonannounced marches and gatherings (Assemblée nationale du Québec, 2012). In response, protests escalated.

As the demands and scope of the student movement expanded, multiple creative actions arose. In many Montréal neighbourhoods, groups of protesters expressed their frustrations by banging their kitchen pots and pans. Protesters also organized nightly marches, often naked, with hopes to demonstrate their vulnerability and non-violence in the face of police violence and brutality. Typically, all supporters wore the carré rouge [red square] which became the symbol for the movement worn by all supporters.

New art practices also appeared to motivate Québec citizens to participate in a dialogue with the student movement. Artist-researcher, Nato Thompson's (2012) “Living as form: Socially engaged art from 1991-2011" suggests that over the last few years, a growing movement of artists choose to interact with timely issues. Thompson (2012) contends that, "socially engaged art is not an art movement, but rather it involves cultural practices that indicate a new global social order" (p.19).

Montréal-based artist, Tina Carlisi's research (2013) describes the significance in collective visual art initiatives to promote critical thinking, increase awareness, and mobilize citizens. One of the most powerful forms of collective art activism during the movement came from the École de la Montagne rouge (EMR). A seven-month initiative led by undergraduate graphic design students from the Université du Québec à Montréal (UQAM), the mission aimed to combine activism, art and education to recruit participants in the Québec student protests (École de la Montagne rouge, n.d.).

By actively participating in the movement, the members extended their learning from the classrooms to public spheres. Not only did EMR members discover new ways of learning through social art practices, but they also began reconstructing alternative practices to reflect the movement (Carlisi, 2013). For instance, members'

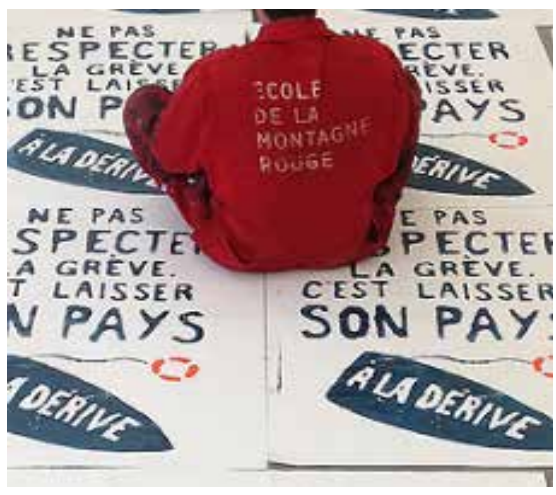

Figure 6. A protestor sits among banners.

Photo Credit: École de la Montagne rouge 
desire to unite and create visual art for the protests increased their sense of autonomy in organizing meaningful projects related to social change (Carlisi, 2013). During a La Presse interview, EMR founder, Guillaume Lepine, reveals the purpose of the creative initiative:

L'idée générale, c'était d'offrir à ceux qui n'avaient pas envie de descendre manifester dans la rue l'occasion d'utiliser les arts comme moyen d'action" [The general idea was to offer those who never felt like protesting in the streets an opportunity to use the arts as a form of action] (Petrowski, 2012, p. 3).

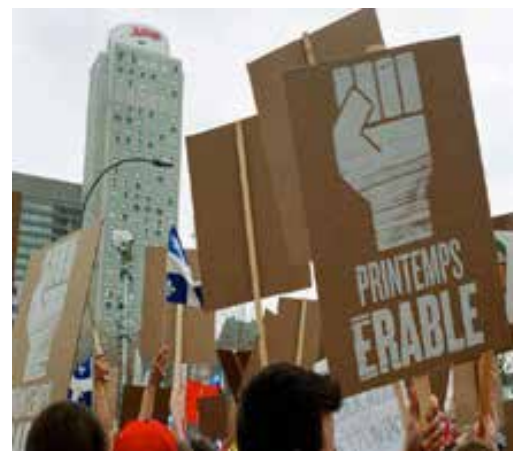

Figure 7. Some signs during the march. Photo Credit: École de la Montagne rouge

EMR members learned about the student movement and how to participate in taking action through the widespread use of poster art, particularly silkscreen posters, such as: teaching the silkscreen process to others, showcasing the protest work of other artists, such as using silkscreen to share inspirational literature related to the student protests, and sharing the visual art pieces and videos produced on their website. The initiative also allowed members of the school to collaborate with multiple artists and organizations supporting the student protests. These collaborations led to the creation of posters, magazines, animations, local events, and other artists' collectives and organizations.

In personal correspondence with a co-author, one of the EMR founding members, Olivier Charland, describes his role. He recounts, "Ensuring proper setup and organization of the initiative from the beginning: organizing workshops, schedules, brainstorm sessions, among a few (O. Charland, personal communication, June 1, 2016). The EMR art produced was critical in contributing to the student protests as he claims, EMR members aimed to spread the message of the protest through multiple art mediums. By focusing on delivering the message as clearly as possible, the members' goal was to reach as many people as possible so they can relate to the message and think about it. For instance, along with the help of the garden architect, members planted 16 red maple trees on Mount Royal Park to form a perfect red square, the symbol of austerity, on Earth Day.

Reflecting upon his involvement, Charland describes it as a valuable learning experience. EMR members "learned how to work, brainstorm, take clients, deal with different situations and also understand to deal with human feelings" (O. Charland, personal communication, June 1, 2016).

The graphic designer reveals it was a crazy learning experience as they learned so much, met so many nice people, and passed through a rollercoaster of emotions throughout the process. Charland hopes:

...that graphic design can play a major role to communicate art project in a clear 
way to the masses. Because the idea is to convince the population and government, not people already into it! So it has to be smart and clean! (O. Charland, personal communication, June 1, 2016)

The EMR rouge is an example of community art highly engaging activists in the Québec student movement. Not only did the EMR provide a strong visual identity to the movement, but the project also represented a unity between the artist, student and politically engaged citizen (Carlisi, 2013). Similar to the C-51 protesters in British Columbia, the creative initiative used visual arts as a tool to unite collective voices on the student protests. EMR members shifted their perspectives on art's role in education as they started to understand art as a tool for social action. Members creatively constructed their own knowledge, using art to engage and empower art students with a desire to have their voices heard.

\section{Conclusion}

We hope that our personal stories of participation and the use of community art as radical pedagogical tools of community transformation resonate deeply with artists and activists. As social justice educators, community activists, and social change artists we try to open souls, disrupt unequal (and often hidden) power structures, challenge oppression, and dream of an alternative reality and a far better world. We have experienced the power of art to engage, disrupt, publicize, unite, conscientize, and potentially transform society. We hope that our stories have illustrated the shared goals and natural connections between the goals and methods of arts and social movements as they engage, critically disrupt and attempt to transform society. In our heARTS we know that an alternative world is achievable and we hope that this research will encourage the continued creative use of the arts in social movements as we paint the world we want.

\section{About the Authors}

Bruno de Oliveira Jayme is an art educator. He has a Ph.D in Interdisciplinary Studies (Visual Arts, Education, and Cultural Geography) from the University of Victoria, where he is also an instructor. Through his SSHRC doctoral scholarship, he explores the role of visual arts in transformative and social movement learning in both Canada and Brazil. He is also the co-director of Tumbleweeds Theatre and Acting School in Victoria. Bruno has brought his art to countries such as India, Brazil, Argentina, Spain, and Canada to explore issues around social and environmental justice. For more information, please visit his homepage at www. brunojayme.com. 
David Monk (corresponding author) is a community activist with a Ph.D in education from the University of Victoria. David is currently a Lecturer at Gulu University where he is helping to start a Department of Lifelong Learning, in addition to an East African hub for communitybased research through the UNESCO Chair in Community Based Research and Social Responsibility in Higher Education Initiative: Knowledge 4 Change. David studies activism and learning in social movements, and is particularly interested in praxis that challenges the hegemony of neoliberalism and unequal power structures. Email: davidfrancismonk@gmail. com?

Emilie Salvi has over five years experience in community-building educational initiatives related to social impacts both in Canada and internationally. She is currently completing an MA in Educational Studies at Concordia University. Her present research focuses on the learning experiences individuals encounter while working abroad in international development programs.

\section{References}

Assemblée Nationale du Québec. (2012). Bill n 78: An act to enable students to receive instruction from the postsecondary institutions they attend. Retrieved from http://www.assnat.qc.ca/en/travauxparlementaires/projets-loi/projet-loi-78-39-2.html

Assembly of First Nations. (2015). Presentation to the standing committee of public safety and national security -bill C-51. Retrieved from http://www.afn.ca/en/national-chief/highlights-from-thenational-chief/presentation-to-the-standing-committee-on-public-safety-and-national-s

Bick, S., \& Rushdia, M. (2012). The movement grows. Our times: Canada's independent labour magazine, 31(3), 20-27.

Belfiore, E., \& Bennet, O. (2008). The social impact of the arts - An intellectual history. London, UK: Palgrave Macmillan.

Benjamin, W. (1999). The work of art in the age of mechanical reproduction, in H. Arendt (Ed.) Illuminations. (pp. 219-253) London, UK: Pimlico. Retrieved from http://ls-tlss.ucl.ac.uk/ course-materials/ARCLG064_44571.pdf (Original work published 1936)

Canadian Bar Association (2015). Bill C-51, Anti-terrorism Act, 2015 Executive Summary. Retrieved from http:/ /iclmg.ca/wp-content/uploads/sites/37/2015/03/15-15-eng-Executive-Summary.pdf

Carlisi, T. (2013). École libre: Visualising a social pedagogic movement. (Master's thesis, Concordia University). Retrieved from http://spectrum.library.concordia.ca/977546/4/Carlisi_MA_ F2013.pdf

Chwe, M. S. Y. (1998). Culture, circles and commercials: Publicity, common knowledge and social coordination. Rationality and Science, 10, 47-75.

Canadian Journalists for Free Expression. (2015). Bill C51: A primer. CJFE. Retrieved from https:// d3n8a8pro7vhmx.cloudfront.net/cjfe/pages/1756/attachments/original/1439701790/ Bill_C51_Primer_0.pdf?1439701790

Engaged Scholar Journal: Community-Engaged Research, Teaching, and Learning 
Clover, D. (2012). Aesthetics, society and social movement learning. In B. Hall, D. E. Clover, J. Crowther, \& E. Scandrett (Eds.), Learning and Education for a Better World The Role of Social Movements (pp. 87-99). Rotterdam, Holland: Sense.

Clover, D. E. (2011). Successes and challenges of feminist arts-based participatory methodologies with homeless/street-involved women in Victoria. Action Research, 9(1), 12-26.

Clover, D. E., \& Stalker, J. (Eds.). (2007). The arts and social justice: Re-crafting adult education and community cultural leadership. Leicester, UK: National Institute of Adult Continuing Education.

Cole, A., \& M. McIntyre (2003). Arts-informed research for public education: The Alzheimer's project. In P. Cranton (Ed.), Charting the learning society: Twenty second national conference of the Canadian Association for the Study of Adult Education proceedings (pp. 45-50). Halifax, NS: Dalhousie University.

Collins, M. (2006). The critical legacy: Adult education against the claims of capital. In T. Fenwick, T. Nesbit, \& B. Spencer (Eds.), Contexts of adult education: Canadian perspectives (pp. 118-127). Toronto, ON: Thompson Educational Publishing.

Darder, A. (2011). Embodiments of public pedagogy: The art of soulful resistance. Policy futures in education, 9(6), 780-801.

Dewey, J. (1934). Art as experience. New York, NY: Minton, Balch \& Company.

École de la Montagne Rouge. À propos. Retrieved from http://ecolemontagnerouge.com/about/

Eisner, E. (2004). The arts and the creation of mind. New Haven, CT: Yale University Press.

Ellis, C. Adams, T., \& Bochner, A. (2011). Autoethnography: An overview. Forum: Qualitative Social Research, 12(1), 1-18.

Elmborg, J. (2010). Literacies, narratives, and adult learning in libraries. New Directions for Adult and Continuing Education, 127, 67-76.

Freire, P. (1970). Pedagogy of the oppressed. (B. Ramos, Trans.). New York, NY: Continuum.

Gale, M., Ades, D., Aguer, M., Fanés, F., (2007). Dali \& film. New York, NY: Museum of Modern Art.

Greene, M. (2000). Releasing the imagination: Essays on education, the arts, and social change. New York, NY: Wiley, John \& Sons.

Hall, B. (2009). A river of life: Learning and environmental social movements. Interface, 1(1), 46-78.

Holden, J. (2008). Democratic culture; opening up the arts to everyone. London, UK: DEMOS

Janis, I. L., \& Mann, L. (1977). Decision making: A psychological analysis of conflict, choice, and commitment. New York, NY: Free Press.

Jordan, T. (1995). The unity of social movements. The Sociological Review, 43(4), 675-692.

Mahmoudi, A., Khoshnood, A., Babaei, A. (2014). Paulo Freire Critical pedagogy and its implications in curriculum planning. Journal of Education and Practice, 5(14), 86-92. Retrieved from https:/ / www.iiste.org/Journals/index.php/JEP/article/viewFile/12993/13309

Marcuse, H. (1965). Repressive tolerance. In R. P. Wolff, B. Moore, \& H. Marcuse (Eds.), A Critique of Pure Tolerance. (pp. 81-123). Boston, MA: Beacon Press.

Milbrandt, M. K. (2010). Understanding the role of art in social movements and transformation. Journal of Art for Life, 1(1), 7-18.

Mota, S. \& Esteves, A.M. (2014). Reinventing emancipation in the 21st century: The pedagogical practices of social movements. Editorial. Interface: a journal for and about social movements, 6(1), $1-24$. 
O'Sullivan, E. (2002). The project and vision of transformative education: Integral transformative learning. In E. O'Sullivan, A. Morell, \& M. O'Connor (Eds.), Expanding the boundaries of transformative Learning (pp. 1-13). New York, NY: Palgrave.

Petrowski, N. (2012 May). Signé école de la montagne rouge. La Presse. Retrieved from: http:/ / collections.banq.qc.ca:81/lapresse/src/cahiers/2012/05/05/C/82812_20120505C.pdf.

Robinson, T. (2006). Do schools kill creativity? Ted Talks. https://www.ted.com/talks/ken_robinson_ says_schools_kill_creativity

Somma, M. (2006). Revolutionary environmentalism. In S. Best \& A. Nocella (Eds.), Igniting a revolution: Voices in defense of the earth. Oakland, CA: AK Press.

Spiegel, J. B. (2015). Rêve Général Illimité? The Role of Creative Protest in Transforming the Dynamics of Space and Time During the 2012 Quebec Student Strike. Antipode, 47(3), 770-791.

Tandon, R., Hall, B., \& Tremblay, C. (2015). Introduction. In Hall, B., Tandon, R., \& Tremblay. C. (Eds.). Strengthening Community University Research Partnerships: Global Perspectives (pp. 1-5). Victoria: University of Victoria Press.

Thompson, J. (2002). Bread and roses: Arts, culture and lifelong learning. Leicester, UK: National Institute of Adult Continuing Education.

Thompson, N. (Ed.) (2012). Living as form: Socially engaged art from 1991-2011. New York, NY: Creative Time.

Engaged Scholar Journal: Community-Engaged Research, Teaching, and Learning 